\title{
The Money-GNP Link: Assessing Alternative Transaction
} \section{Measures}

\author{
R. W. Hafer
}

$\mathrm{E}$

MPIRICAL research strongly suggests that the growth of $\mathrm{M1}$ - a measure of transaction balances - is more closely related to GNP growth than are the broad ef monetary measures. Yet, at its October 1982 meeting, the Federal Open Market Committee (FOMC), which establishes monetary policy for the Federal Reserve system, decided to attach relatively less importance to observed movements in $\mathrm{M} 1$ in formulating policy. Instead, it placed increased significance on the behavior of broader, nontransaction-oriented measures, such as M2 and M3.

This decision came about for two reasons: First, some members of the FOMC believed that the behavior of M1 had been and would continue to be distorted by the shifting of funds among new types of monetary instruments that resulted from financial deregulation. Second, velocity developments in 1982, which con-

R. W. Hafer is a senior economist at the Federal Reserve Bank of St. Louis. Jane Mack provided research assistance.

NOTE: The empirical work presented here is based on the unrevised M1 data.

1Transaction balances refer to those balances that are available for immediate spending, such as demand deposits. Empirical evidence comparing narrow (that is, transactions-oriented) and broad monetary definitions is presented in Carlson and Hein (1980). Hafer (1981) and Batten and Thomton (1983). An alternative view, advocating the use of broader measures of money or debt, is expressed in Friedman (1981, 1982) and Morris (1982). The use of broad monetary aggregates or debt measures in the conduct of policy is examined critically by Lawler (1981) and Davidson and Hafer (1983). tinued into 1983 , raised doubts about the stability of the relationship between $\mathrm{M} 1$ and nominal income (GNP).2

Much of the uncertainty about the usefulness of M1 as a transactions measure arises because it includes currency and demand deposits - traditionally re. garded as "money" - plus interest-bearing checkable deposits, such as negotiable order of withdrawal (NOW) accounts, automatic transfer system (ATS) accounts, and credit union shave drafts. ${ }^{3}$ Some have argued, however, that these latter deposits ${ }_{f}$ "while

"For a general discussion, see "Monetary Policy Report to Congress" (1983), especially pages 132-35. See also Solomon (1983).

${ }^{3}$ The concept of money as that asset used expressly for transaction purposes has a long history in monetary economics. Lauchin Currie (1935), for example, makes clear the distinction between the concept of money, defined as currency plus demand deposits, and broader measures that incorporate savings-type deposits:

There is, however, an important distifction between means of payment and what may be regarded by individuals as equivalent to means of payment. The deposits, in this respect, do not differ essentially from holdings of government securities, call loans, or, indeed, any property possessing good marketability which by sale can be converted into meens of payment. It is no more correct to say that one can spend a time deposil than a government secufity. Both must first be exchanged for cash or deposits subject to check before they can be spent.

This distinction belween money and "near money" also is noted by Martin Brontenbrenner (1945): "No monetary commodity can have any use other than cash balance uses, "where "cash balance uses" refers to those iterns "held expressly (consciously) for the purpose of future difect exchange for other goods." Recent attempts to determine empinicaly the transaction uses of current monetary measures are represented by Barnett (1980) and Spindt (1983). 
serving the transaction needs of holders, have many of the characteristics of savings accounts." Thus, the nature of $\mathrm{M} 1$ as a measure of transaction balances has come under question.

In this article, we investigate the relationship beween two alternative measures of transaction balances and GNP. One measure is the current M1 aggregate. Because of the difficulty in reliably determining what proportion of other checkable deposits is held as savings instead of Iransaction balances, they are excluded from our altemative measure, called adjusted M1. Thus, adjusted M1 is simply M1 minus other checkable deposits, that is, M1 less its interest-bearing components. ${ }^{5}$ By examining the evidence obtained from using these polar definitions of transaction batances, some light may be shed on the question whether recent movements in $\mathrm{M} 1$, especially those in 1982 and early 1983, accurately reflect the actual monetary stimulus to the economy.

\section{A MODEL OF THE DEMAND FOR TRANSACTION BALANCES}

Useful theoretical models have been developed to analyze the effect of the interest payment prohibition on demand deposits. These models provide a foundation from which to analyze the impact of the introduc tion of interest-bearing checkable deposits. From these models, we can predict some of the effects of the repeal of interest prohibtion on transaction deposits which, in essence, occurred when Now accounts became available nationwide."

In a general model developed by Santomero, the household is assumed to allocate its wealth among various assets in order to maximize the return from its consumption activities, "The household's initial endowment of wealth may be held as currency, demand deposits, savings deposits or commodity inventories. The savings deposit pays a positive, explicit interest rate, $\boldsymbol{r}^{\mathrm{s}}$. Demand a aposits yield some implicit interest, $r^{d}, 0 \leqslant r^{d} \leqslant r^{3}$ Because savings cannot be traded

\footnotetext{
4"Monetary Policy Report to Congress," p. 134.

5"Adjusted $M$ 1" is not identical to the pre-1980 M1 definition. Unlike the previous measure, adjusted M1 includes travelers checks and excludes deposits due to foreign commercial banks and official institutions. For a comparison between old and current M1, see Hafer (1980).

${ }^{6}$ It should be noted that the analysis concerns household behavior only: businesses currently are not allowed to hold NOW accounts.

${ }^{7}$ Santomero (1974).

${ }^{8}$ These are returns on the marginal dollar held in each deposit group.
}

directly for commodities, the model also posits transaction costs for currency and demand deposits that are strictly lowet than those for savings. ${ }^{9}$ Thus, savings are viewed as being a temporary store of funds. Moreover, the theoretical model predicts that "the savings asset will only be used as a temporary store of working balances for intra period use if the interest rate differential $\left[r^{s}-r^{1}\right]$ is sufficient to compensate the household for the extra cost of going to the bank. If this condition is not satisfied, the savings asset will not be used and demand deposits will become the temporary store of funds." 10 Thus, as the rate paid on demand deposits (implicit or explicit) approaches the rate paid on savings deposits, households will increase their average holdings of demand deposits relative to sav ings deposits. ${ }^{11}$ In this event, funds stored in savings deposits will be converted into demand deposits, which will now possess the dual characteristics of a transactions medium and a "temporary store of funds." 12

${ }^{9}$ Let $\alpha_{\mathrm{pG}}$ and $\alpha_{\mathrm{CG}}$ represent the transactions cost of obtaining commodities $(G)$ by means of using demand deposits $(D)$ and currency (C), respectively. If $\alpha_{S D}$ and $\alpha_{S C}$ represent the cost of converting savings deposits into demand deposits or currency, respectively, then the transactions cost of using savings deposits to acquire commodities $\left(\alpha_{S G}\right)$ is either $\alpha_{S G}=\alpha_{S O}+\alpha_{D G}$ or $\alpha_{S G}=\alpha_{S C}+\alpha_{C G}$. The household's cost of transferring funds from savings to demand deposits (ignoring currency) and the relative return from holding savings deposits are crucially related. As Santomero notes, "the return from the short-term interest bearing asset [ $\mathrm{r}^{\mathrm{s}}$ ] must be sufficient to compensate the household for the additional cost of withdrawing funds from S [savings] and not D [demand deposits]," See Santomero (1974)

${ }^{1}$ Ibid., p. 97, italics added.

${ }^{11}$ See also the analyses of Barro and Santomero (1972) and $M$. Klein (1974)

72Formally, the solutions for average demand deposit holdings ( $\bar{D})$ and average savings deposit holdings (S) are given as

$$
\begin{aligned}
& \bar{D}=\sqrt{\frac{Y\left(\alpha_{S}-\alpha_{D C}\right)}{2\left(r^{s}-r^{d}\right)}}-\sqrt{\frac{Y h \alpha_{D C}}{2\left(r^{d}-r^{9}\right)}}-\sqrt{\frac{Y(1-h) \alpha_{D G}}{2\left(r^{A}-r^{9}\right)}} \\
& \bar{S}=\frac{1}{2} Y T-\sqrt{\frac{Y\left(\alpha_{S}-\alpha_{D C}\right)}{2\left(r^{s}-r^{c}\right)}} \\
& \text { where } Y=\text { rate of consumption of lump sum income payment } X \\
& \text { across intervals } \mathrm{T}(\mathrm{Y}=\mathrm{X} / \mathrm{T}) \text {, } \\
& \mathrm{h}=\text { proportion of transactions using currency, } \\
& (1-h)=\text { proportion of transactions using demand deposits, } \\
& \alpha_{D C}=\text { cost of converting demand deposits into currency, } \\
& \text { and } \left.r^{9}=\text { return on commodity inventories }(r) 0\right) \text {. }
\end{aligned}
$$

Holding transactions costs constant, as the rate on demand deposits $\left(r^{\circ}\right)$ approaches that on savings deposits $\left(r^{3}\right)$, the first term in the demand deposit equation becomes indefinitely large as does the expression under the radical sign in the savings equation. The consequence, clearly, is for average demand deposit holdings $(\bar{D})$ to increase relative to average savings deposit holdings $(\bar{S})$. 
The crucial element in this analysis is the difference between the rates on demand deposits and savings. If the demand deposit rate is both "competitive," as suggested by Klein, and Barro and Santomero, and close to the rate paid on savings accounts, removing the interest prohibition on demand deposits lassuming that $r^{\text {ch }}$ cannot exceed $r^{s}$ should not appreciably affect the household's allocation of funds. Evidence by Start $z$ however, indicates that the implicit rate paid on demand deposits lessentially through remission of serm vice charges/ is only about one-half of the alternative savings rate ${ }^{13}$ Consequently, allowing explicit interest payments on checkable deposits that approach the rate paid on savings deposits, according to the model, would attract funds from savings deposits that pay a similar rate of return and are relatively less liquid.

\section{THE IMPACT OF INTEREST PAYMENTS ON CHECKABLE DEPOSITS: SOME EVIDENCE}

NOW accounts were made available to households on a nationwide basis beginning in January 1981. Before then, they were available only in the New England states." Frodin and Startz examined the effects of the early NOW experience on money demand estimates for the New England states relative to the rest of the United States. ${ }^{15}$ Their results indicate that, after 1975 , the introduction of NOW accounts increased personal transaction balances by about 37 percent; in terms of total money demand, the result was an increase of about 9 percent.

In another recent study, Radecki and Wenninger examine money demand functions for the consumer and nonfinancial business sectors to determine, among other things, the effect of NOW accounts on the two groups during 1981 and 1982 . Based on a series of post-sample forecasts, they conclude that "the increase in NOW accounts during that year [1981] could not have represented just a substitution of demand

\footnotetext{
${ }^{13}$ Startz (1979) estimates two series on the implicit interest on demand deposits. In 1975, the rate was calculated to be 2.47 percent and 2.80 percent. These implicit returns paid on demand deposits are compared with the passbook savings rate at commercial banks of 4.87 percent and the passbook rate at savings and loans of 5.24 percent.

${ }^{14}$ NOW accounts were offered first in June 1972 by the Consumer Savings Bank of Worcester, Massachusetts. Initially, NOWs were limited to mutual savings banks. In January 1974, New England commercial banks were authorized to offer NOW accounts. See Klein (1978).

${ }^{15}$ Frodin and Startz (1982).
}

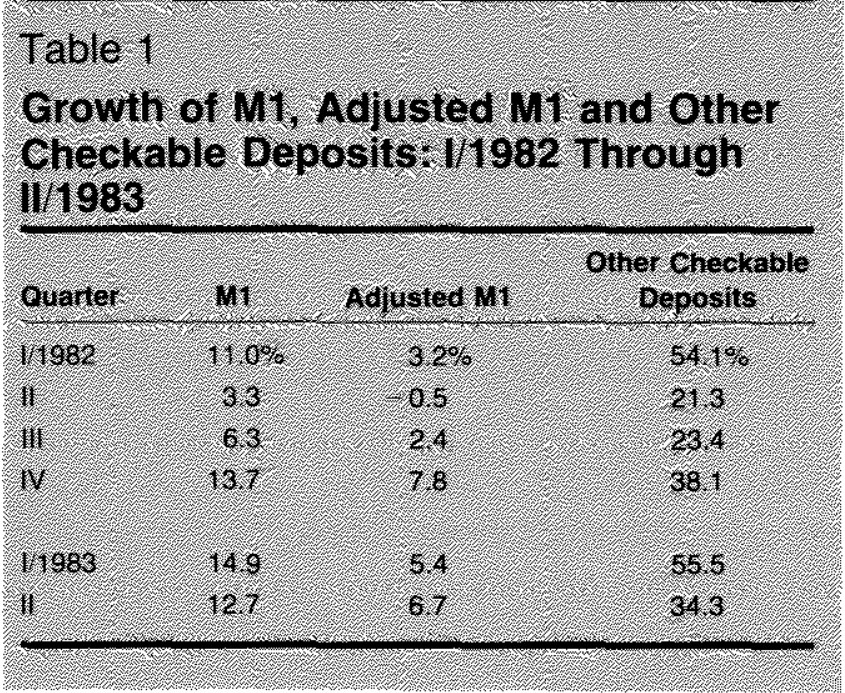

deposits for NOW account deposits, leaving the demand for total money balances unchanged."16 More over, their evidence indicates that the rapid growth of M1 during 1982 was due to a continuing flow of funds away from non-M1 sources into NOW accounts as new accounts were opened..$^{17}$ Specifically, they claim that about $\$ 8$ billion of the new NOW accounts originated outside M1.

The results of other studies by Johannes, and Johannes and Rasche, on forecasting the M1 money multiplier imply that there was a portfolio shift between time deposits and transaction accounts during the early part of $1981,{ }^{18}$ They found that a level shift adjustment was necessary for five of the seven ratios used in calculating the multiplier. Their results are roughly consistent with the Board of Governors' staff projections that, during early 1981,20 percent to 25 percent of the funds shifting to NOW accounts were from non* demand deposit sources.

During 1982, the growth of M1 far exceeded that of adjusted $\mathrm{M} 1$. The figures in table 1 indicate that M1 averaged about an 8.5 percent growth rate in that year. Adjusted $M 1$, on the other hand, grew an average rate of only 3.2 percent. In early 1983 , this divergence was

\footnotetext{
${ }^{15}$ Radecki and Wenninger (1983), p. 5 , italics in original. It should be noted that the results of Radecki and Wenninger are based on data that has been questioned. Consequently, some caution is advised in interpreting their findings.

${ }^{17}$ Data presented by Radecki and Wenninger suggest that the number of new NOW accounts opened between November 1981 and November 1982 totaled 3.32 million, an increase of 22 percent.

18 Johannes (1981), Johannes and Rasche (1981). An opposite conclusion is reached by Tatom (1982).
} 
even greater: $M 1$ increased at an average annual rate of 13.8 percent and adjusted M1 at a 5.9 percent average rate.

A recent study by Judd and McElhattan helps explain these divergent growth rates. In their study, Judd and McElhattan argue that the M1 series overstated the "effective" money growth rates during 1982-83. This overstatement arises from an interest-rate-induced in " crease in the quantity of money balances demanded by the public. That is, the sharp drop in market rates during late 1982 precipitated an increase in the quantity of money balances demanded to which "the Federal Reserve responded by allowing money to grow faster than originally targeted."19

The data in table 1 indicate that this increase in money growth exists largely in the interest-bearing component of $\mathrm{M} 1$, not in the adjusted M1 series. The Judd-McElhattan analysis, combined with the data in table 1, suggests that demand deposits and currency have reacted differently to changes in market interest rates than did the interest-bearing component of M1. Indeed, other checkable deposits appear to be more interest-elastic than the non-interest-bearing bal ances. Moreover, Judd and McElhattan find that an M1 series "adjusted" for the increased quantity of money demanded due to the sharp interest rate decline in late 1982 explains econonic activity behavior better than M1 during the $1982-83$ period. Thus, the implication is that the increased quantity of money demanded was not used to fund transactions but, rather, was held as a store of funds.

The discussion thus far indicates that the increase in M1 in 1981 is partially attributable to the shifting of funds from time deposits to transaction balances. In 1982, the divergent behavior of $\mathrm{M} 1$ and adjusted M1 also suggests that the growth in the interest-bearing components of M1 was, in part, for non-transaction purposes. This result is "predicted" by the theoretical model discussed above. The interesting policy question that emerges from these results is: Does M1 have the same influence on economic activity as it did before these new interest-bearing deposits were made available? Moreover, do transaction balances that do not carry explicit interest payments display the same relationship to total spending before and after the change in the financial envionment? The remainder of this article attempts to answer these questions.

\footnotetext{
79 Judd and McElhattan (1983), p. 46
}

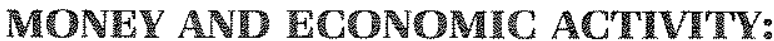 WHCH MU?}

The nationwide introduction of NOW accounts attracted funds from both demand deposits and nonM1 sources. During 1981, the growth of demand deposits fell dramatically as households shifted some of these funds into NOW accounts, For example, adjusted M1 decreased at rates of 21.4 percent 4.7 percent and 2.3 percent, respectively, during the first three quarters of 1981. This drop signified that the public was less willing to hold transaction balances that did not pay explicit interest at every level of real income and interest rates, ${ }^{20}$ Other things unchanged, adjusted-M1 velocity should have shown a marked upward level shift during this period.

Chart 1 plots the levels of adjusted M1 and M1 velocities for the period $1 / 1960$ to II/1983. There is no discernible difference between the two series before the mid1970 s, because other checkable deposits were a minor part of the public's money holdings. The introduction of ATS accounts, New England NOWs and credit union share draft accounts produced the divergent behavior of the two series since the mid-1970s. The biggest de-

${ }^{20}$ This assertion is borne out by estimates of a conventional money demand equation for adjusted M1. For example, using the period U/1960 through $\mid / / 1983$, the adjusted-M1 equation yields the result (absolute value of $\mathrm{t}$-statistics in parentheses):

$$
\begin{aligned}
\ln (\mathrm{M} / \mathrm{P})_{t}= & -0.247-0.011 \mathrm{D} 1+0.047 \ln \mathrm{y}_{\mathrm{t}} \\
& (2.64)(2.63)(3.24) \\
& -0.032 \ln \mathrm{r}_{\mathrm{t}}+0.970 \ln (\mathrm{M} / \mathrm{P})_{\mathrm{t}}, \mathrm{1} \\
& (6.81) \quad(63.35)
\end{aligned}
$$

$\overline{\mathrm{A}}^{2}=0.987 \quad \mathrm{SE}=0.0096 \quad \mathrm{Dh}=-0.46$

where $P$ is the GNP deflator $(1972=100)$, y is real GNP $(\$ 1972)$, is the three-month Treasury bill rate and $D$ is is $(0,1)$ dummy term that equals 1.0 for the period $1 / 1974$ to $/ / 1983$, zero elsewhere. These resuits indicate an abnormally slow adiustment speed (3 percent per quarter) and long-term income and interest elasticities that are quite large relative to standard results.

Accounting for a level shift in the function in 1981, however, restores the underlying economic relationship between real money balances and its determinants. Introducing another intercept shift term (D2), defined as 1.0 for the period $1 / 1981$ to $1 / / 1983$ and zero elsewhere, the results are

$$
\begin{aligned}
& \text { In }(\mathrm{M} / \mathrm{P})_{\mathrm{t}}=-0.373-0.023 \mathrm{D} 1-0.042 \mathrm{D} 2 \\
& \begin{array}{lll}
(4.56) \quad(5.46) \quad(5.67)
\end{array} \\
& +0.081 \ln y_{1}-0.028 \ln r_{1}+0.825 \ln (M / P)_{1-1} \\
& \text { (5.97) (6.93) }(29.01) \\
& \overline{\mathrm{R}}^{2}=0.991 \quad \mathrm{SE}=0.0081 \quad \mathrm{Dh}=0.80
\end{aligned}
$$

These results are similar to numerous other studies in terms of the estimated speed of adjustment ( 18 percent per quarter) and the income and interest elasticities. The significance of the D2 coefficient supports the contention of a downward level shift in the function. 
Chot 1

\section{Velocity of $M I$ and Adjusted $M I$}

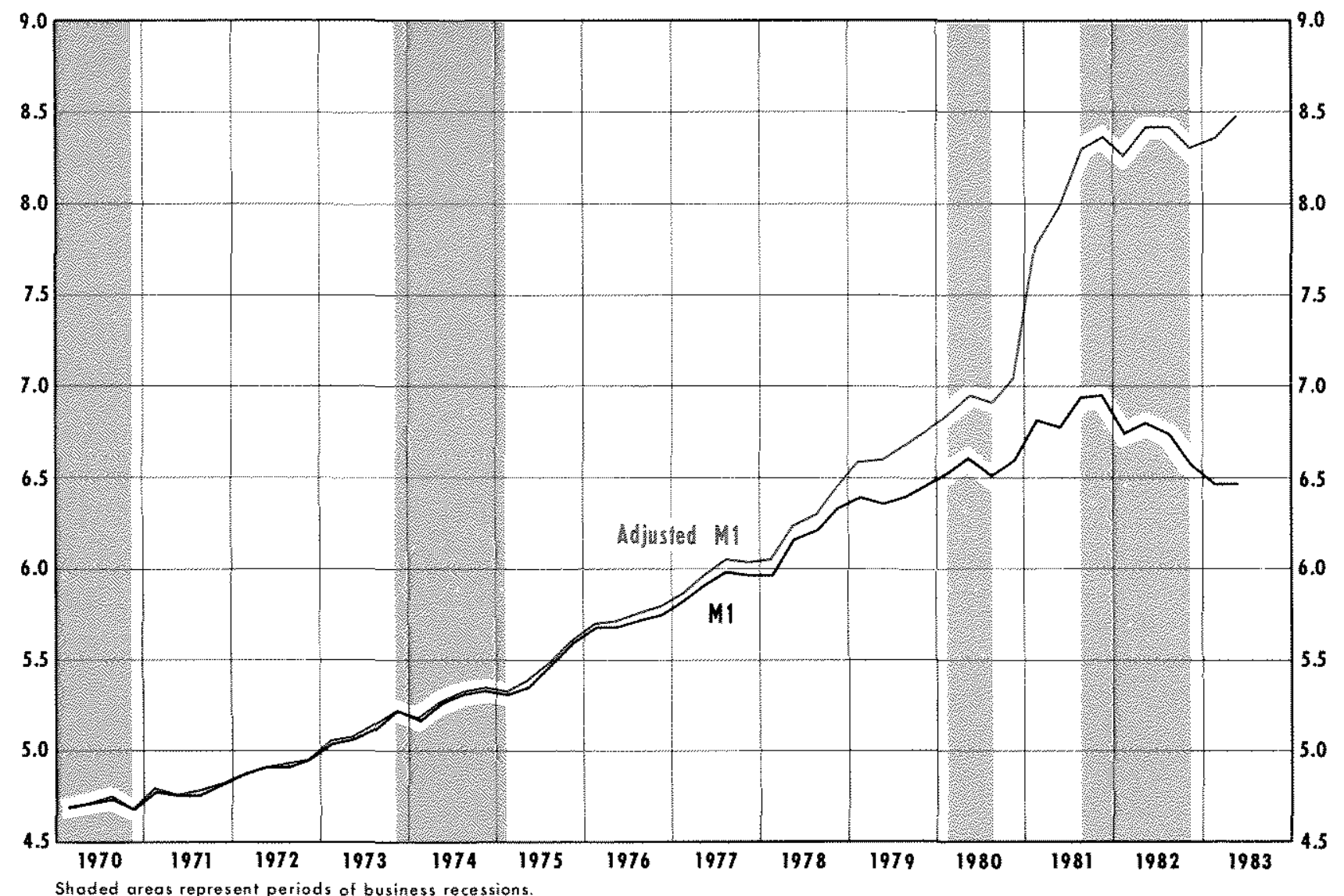

viation in the respective velocity measures occurs in 1981 when NOW accounts were made available nationwide. For example, in $\mathbf{1} / 1981$, M1 velocity increased at a 13.8 percent rate, while adjusted $M 1$ velocity increased at an unprecedented $\mathbf{4 0 . 0}$ percent rate. For the year as a whole, M1 velocity increased at an average rate of 5.3 percent, within two standard deviations of its 3.2 per cent average growth since 1960. Adjusted M1 velocity, in contrast, grew at an average rate of 17.4 percent.

Again in 1982, the growth of velocity measured by adjusted M1 diverged sharply from that of M1. For example, during 1982, adjusted-M1 velocity declined at an average 0.72 percent rate; $M 1$ velocity declined, on average, at a 5.62 percent rate. Several researchers have attempted to explain this sharp drop in M1 velocity. Tatom, for example, argues that some of the drop in M1 velocity growth during the last recession can be accounted for by the cyclical response of velocity to the recession.: As noted earlier, Judd and McElhattan argue that the M1 measure overstates the growth of transaction balances in 1982 that influences economic activity. Using their adjusted-M1 series, they find that "Islimulations of velocity, real GNP and inflation ... were moге accurate than those using measured M1."22

Has the behavior of the interest-bearing component of M1 during the past one and one-half years led to a substantial change in its empirical relationship with GNP growth? Once we have captured the expected velocity shift in adjusted M1 due to financial innova* tions in 1981, has there been any deterioration in its relationship with GNP growth?

To determine which measure of money, M1 or adjusted M1, better explains GNP growth, both were used

\footnotetext{
${ }^{21}$ Tatom (1983).

${ }^{22} \mathrm{Judd}$ and McElhattan, p. 46.
} 
in estimating a variant of the reduced-form $\mathrm{St}$. Louis GNP equation ${ }^{23}$ First, in-sample estimates using $M 1$ and adjusted M1 are presented for the period $/ / 1960$ to IV/1979 and are used as a basis for comparison. ${ }^{24}$ the sample period then is updated through IU/1983, and the equation is re-estimated.

Because the constant term in the reduced-form GNP equation represents the average growth rate of velocity, a failure to capture the intercept shift caused by neaction to the introduction of nationwide NOW accounts would lead to biased coefficient estimates. ${ }^{25}$ Consequently, a $(0,1)$ dummy variable is used to capture the short-lived aberration in adjusted-M1 velocity growth during 1981. This term (D1981) equals 1.0 for $1 / 1981$, II/1981 and III/1981, and zero elsewhere.

\section{In-Sample Estimates: 1960-1979}

To gauge the presumed deterioration in the moneyGNP link, the two altemative money measures are used initially to explain economic activity during a previous, relatively untroubled period. The results of estimating the reduced-form GNP equation using both monetary definitions for the period I/1960-IV/1979 are presented in table $2^{26}$

Not surprisingly, the empirical estimates are quite similar. In terms of overal fit, the coefficient of deter mination $\left(\overline{\mathbf{R}}^{2}\right)$ of the M1 equation is slightly greater than that for adjusted M1, albeit by less than 3 percent. This slight improvement also is reflected in the relative standard errors of the equation (SE). Moreover, as the Dur-

${ }^{23}$ The modet estimated here is presented in Tatom (1981). The basic model is expressed in the form

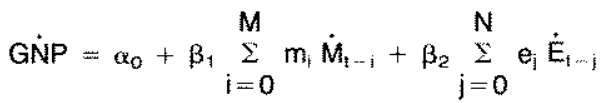

$$
\begin{aligned}
& +\beta_{3} \underset{k=0}{Q} p e_{k} \dot{P}_{i \ldots 1 \ldots k}^{e}+S_{i}+\varepsilon_{t}
\end{aligned}
$$

where $\dot{M}$ is the growth of money, $\dot{E}$ is the growth of high-employment federal expenditures, $P^{\theta}$ is the change in the relative price of energy and $S$ is a variable entered to capture the effect of major strikes on GNP.

${ }^{24}$ This specific sample period is used because monetary policy procedures changed after this date, monetary policy in 1980 was influenced by the Special Credit Controls program, NOW accounts were legalized nationwide in 1981 and, finally, financial deregulation accelerated after this period.

${ }^{25}$ See Maddala (1977), pp. 155-57.

${ }^{26}$ The monetary and fiscal actions measures are estimated using a fourth-degree Almon polynomial with both endpoints constrained. The relative energy price variable is estimated using a third-degree polynomial without endpoint constraints.

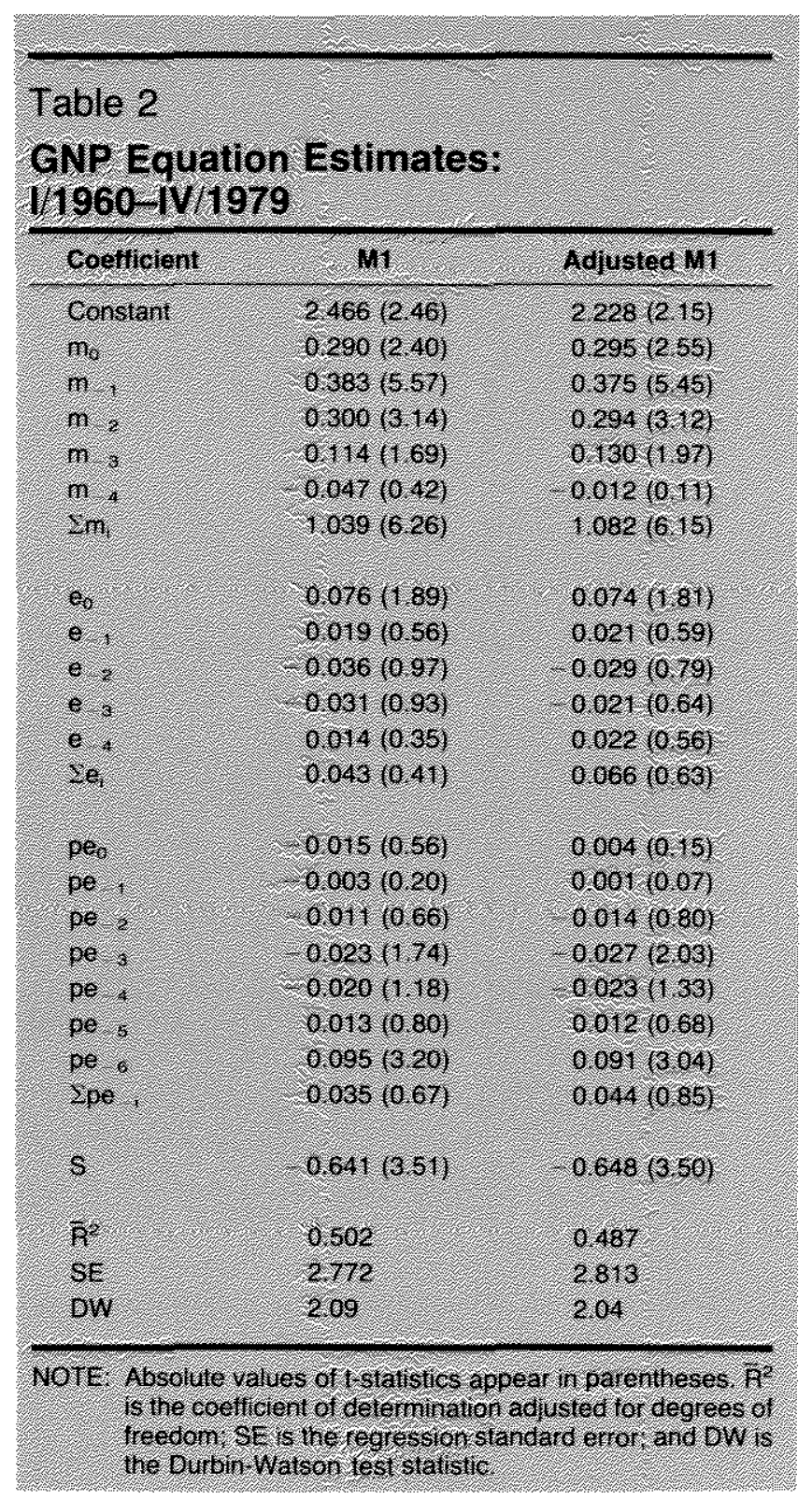

bin Watson (DW) test statistics indicate, neither equation is hampered by first-order sertal correlation.

The results for the individual variables also show little difference. In each instance, the pattern of the estimated lags is similar in magnitude and signifcance. For example, the hypothesis that the cumulative effect on GNP growth of a change in money growth is unity cannot be rejected for $\mathrm{M} 1$ (t $=0.39$ ) or adjusted M1 $(t=0.60$ ). Similarly, we cannot reject the hypothesis that fiscal actions and changes in relative energy prices have no lasting, significant effects on the growth of GNP. 'Thus, in terms of overall fit and individual coefficient estimates, there appears to be little difference between M1 or adjusted M1 in explaining GNP growth during the period 1960-79. 


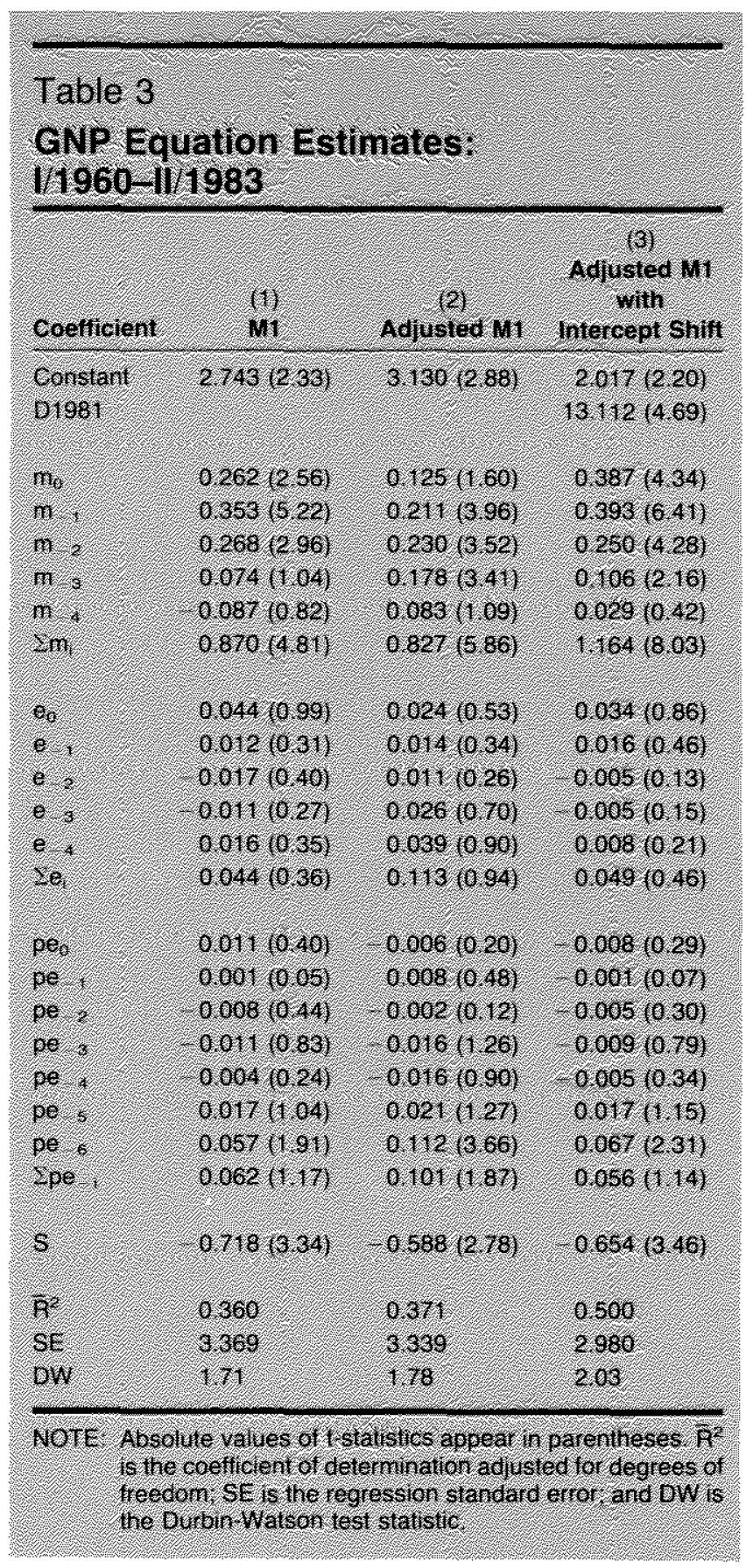

\section{In-Sample Estimates: $1960-1983$}

The GNP estimates using the post -1979 data indicate a substantial deterioration in the equation's explanatory power. As reported in columns 1 and 2 of table 3 . there is almost a 30 percent reduction in explanatory power regardless of the M1 measure used. ${ }^{27}$ Moreover.

\footnotetext{
${ }^{27} \mathrm{~A}$ similar deterioration is documented, although not explained, in Batten and Thornton (1983)
}

the summed effect of money growth has declined substantially. For example, using the 1960-79 sample, a 1 percentage-point change in M1 growth has a cumulative 1.039 percentage-point change in GNP growth. When the 1960-83 sample is used, however, the estimate of this cumulative effect drops to a 0.870 percentage point change. A similar result occurs when the sample period is updated and adjusted $\mathrm{M} 1$ is used as the monetary variable $(1.082$ percent to 0.827 percent $)^{2 s}$

The problem with the adjusted M1 results shown in column 2 of table 3 , as noted earlier, is that the adjusted M1 results are not reliable unless the 1981 NOW account effect has been taken into account. Thus, the GNP equation using adjusted M1 was re-estimated for the 1960-83 period incorporating the intercept shift term. These results, presented in column 3, show that the intercept shift term (D1981) is posifive and statistically significant; thus, the hypothesis that the constant term was subject to a significant displacement during 1981 is not rejected by the data. The importance of capturing this effect is evidenced by the dramatic change in the equation's explanatory power and in the coefficient estimates of the money variable. ${ }^{29}$

When compared with the 1960-79 estimation results, the adjusted M1 equation with the intercept adjustment shows no deterioration in overall fit; the $\overline{\mathbf{R}}^{2}$ increases from 0.487 to 0.500 , compared with the approximately 30 percent decline found using $\mathrm{M1} .^{30}$ Not only is the overall fit of the equation actually imm proved, but the drop in the summed coefficient estimates on adjusted M1 that appears when comparing

${ }^{28}$ It should be noted that neither sum estimate is statistically different from unity.

${ }^{29}$ Another procedure also was used to account for the rapid adjustedM1 velocity growth in 1981. Because GNP does not respond immediately to changes in money growth, a rapid increase (decrease) in money growth during a quarter wits appear as a sharp declire (increase) in velocity. Thus, to abstract from the declines in adiusted M1 growth during the NOW account introduction, a $(0,1)$ dummy term is used to form an interaction variable with the adjusted $\mathrm{M} 1$ growth. This variabie takes on the value of zero in all quarters except I/1981, I//1981 and II/1981, when it equals actual adiusted $M+$ growth. As expected, the outcome using this approach is quite similar to the sthift-adjusted model in table 3 . Again the $\overline{\mathrm{R}}^{2}(0.50)$ is increased by about 40 percent relative to the $M 1$ equation. The deterioration in the coefficient on the summed effect of money growth ( $\mathrm{\Sigma m}$ ) found using $\mathrm{M} 1$ disappears; the estimated cumulative effect is 1.139 . This result provides funther evidence on the relative usefuness of adjusted $\mathrm{Ml}$ in explaining GNo growth.

${ }^{30}$ For completeness, we also estimated the M1 equation with the D1981 variable; the estimated coefficient was not siatistically significant. 
the results in tables 2 and 3 vanishes as well: a 1 percentage point change in adjusted M1 growth is now estimated to have a cumulative impact of 1.164 percentage-point change in GNP growth, slightly high er than the 1.082 percentage-point change reported for the $1960-79$ sample. Thus, when the velocity change during 1981 caused by the NOW account introduction is taken into account, the adjusted M1 measure explains the growth of GNP better than does $M 1 .^{31}$

\section{CONCLUSON}

It has been argued that M1, as it is currently defined, may give a distorted view of actual policy actions on the economy. This problem arises from the public's willingness to view some portion of interest-bearing checkable deposits as savings-type balances. Unfortunately, there currently is no reliable procedure by which we can disentangle the transaction from the non-transaction shares of these deposits. This is especially true in terms of anticipating what those proportions will be in the future.

To investigate the validity of the alleged problem with $\mathrm{M} 1$, an alternative $\mathrm{M} 1$ measure was derived that excluded all interest-bearing checkable deposits. This adjusted M1 measure - defined simply as M1 less other checkable deposits - was used in a reducedform GNP equation, and the results were compared with estimates obtained using M1. Estimates derived from the $1960-83$ sample period indicate that, once the distorting effects of the NOW account introduction in 1981 are accounted for, the adjusted M1 series explains GNP growth better than M1.

Although the results suggest that recent criticism of the M1-GNP link is not unwarranted, they strongly deny the associated claim that the link between transactions money and GNP has been damaged irreparably. Instead, the evidence suggests that a more fruitful approach would be to sharpen the distinction between transaction deposits and those held for both . transactions and savings.

\footnotetext{
${ }^{3+}$ The results suggest that the "other checkable deposit" (OCD) component of $M 1$ may be dominated by the growth of adjusted $M 1$ in explaining the growth of GNP. To test this, OCDs were added to the adjusted $M 1$ equation as a separate set of independent variables. The equation was then re-estimated for the $\mathrm{H} / 1964-\mathrm{H} / 1983$ sample period; the sample period is shorter due to the limited data availability for OCDs. Based on a standard Futest, adding OCDs does not significantly increase the explanatory power of the equation $\left(\mathrm{F}_{62}^{3}=\right.$ 1.62).
}

\section{PEFETENCES}

Barnett, William A. "The Optimal Level of Monetary Aggregation," Journal of Money, Credit and Banking (November 1980), pp. $687-710$.

Barro, Robert J, and Anthony M. Santomero. "Household Money Holdings and the Demand Deposit Rate." Joumal of Money, Credit and Banking (May 1972), pp. 397-413.

Batten, Dallas S., and Daniel L. Thornton. "M1 or M2: Which is the Better Monetary Target?" this Review (June/July 1983), pp. 3642.

Bronfenbrenner, $M$. "Some Fundamentais in Liquidity Theory," Quarterly Journal of Economics (May 1945), pp. 405-26.

Carison, Keith M., and Scott E. Hein. "Monetary Aggregates as Monetary Indicators," this Review (November 1980), pp. 12-21.

Currie, Lauchlin. The Supply and Control of Money in the United States (Harvard University Press, 1935).

Davidson, Lawrence S., and A. W. Hafer. "Some Evidence on Selecting an Intermediate Target for Monetary Policy," Southern Economic Journal (October 1983), pp. 406-21.

Friedman, Benjamin M. "The Roles of Money and Credit in Macroeconomic Analysis," in J. Tobin, ed., Macroeconomics, Prices, and Quantities: Essays in Memory of Arthur M. Okun (Brookings, 1983), pp. $161-89$

. "Time to Reexamine the Monetary Targets Framework," New England Economic Review (March/Aprił 1982), pp. 15-23.

Frodin, Joanna H., and Richard Startz. "The NOW Account Experiment and the Demand for Money." Joumal of Banking and Finance (June 1982), pp. 179-93.

Hater, R. W. "The New Monetary Aggregates," this Review (February 1980$)$, pp. 25-32. $13-18$.

Johannes, James $M$. "Testing the Shift Adjustment in the Federal Reserve's New Shift Adjusted M1B," Economics Letters $(8,1981)$, pp. $367-72$.

Johannes, James M., and Robert H. Rasche. "Forecasting Multpliers for the 'New-New' Monetary Aggregates," Shadow Open Market Committee Policy Statement and Position Papers. Working Paper No. PPS-81-8 (Center for Research in Government Policy \& Business, University of Rochester, September 1981), pp. $39-49$.

Judd, John P., and Rose McEthattan. "The Behavior of Money and the Economy in 1982-83," Federal Reserve Bank of San Francisco Economic Review (Summer 1983), pp. 46-51.

Klein, Benjamin. "Competitive Interest Payments on Bank Deposits and the Long-Run Demand for Money," American Economic Review (December 1974), pp. 931-49.

Klein, Michael A. "Deposit Interest Prohibition, Transactions Costs, and Payments Patterns: A Theoretical Analysis, "Metroeconomica (November/December 1974), pp. 144-52.

"The Implicit Deposit Rate Concept: Issues and Applications," Federal Reserve Bank of Richmond Economic Review (September:October 1978), pp. 3-12.

Lawler, Patrick J. "The Large Monetary Aggregates as Intermediate Policy Targets," Voice of the Federal Reserve Bank of Dallas (November 1981), pp. 1-13.

Maddala, G. S. Econometrics (McGraw-Hill, 1977).

"Monetary Policy Report to Congress." Federal Resene Bulletin (March 1983) 
Morris, Frank $E$. "Do the Monetary Aggregates Have a Future as Targets of Federal Reserve Policy?" New England Economic Review (March/April 1982), pp. 5-14.

Radecki, Lawrence J, and John Wenninger. "Shifts in Money Demand: Consumers versus Business." Federal Reserve Bank of New York Quarterly Review (Summer 1983), pp. 1-11.

Santomero, Anthony M. "A Model of the Demand for Money by Households," Journal of Finance (March 1974), pp. 89-102.

Solomon, Anthony M. "Interpreting Monetary Policy in a Period of Change." Remarks before the Second Annual Conference on Current Financial Issues. Financial Executives Institute, Washington, D.C. (December 7,1983 ).
Spindt, Paul A. "Money is What Money Does: A Revealed Production Approach to Monetary Aggregation," (Board of Governors of the Federal Reserve System, 1983, processed).

Startz, Fichard. "Implicit Interest on Demand Deposits," Journal of Monetary Economics (October 1979), pp. 515-34.

Tatom, John A. "Energy Prices and Short-Run Economic Performance," this Review (January 1981), pp. 3-17.

. "Recent Financial Innovations: Have They Distorted the Meaning of M1?" this Review (Apris 1982), pp. 23-35.

"Was the 1982 Velocity Decline Unusual?" this Review (August/September 1983), pp. 5-15. 